\title{
EFFECT OF DIFFERENT LEVELS OF WATER STRESS AND HUMIC ACID APPLICATION ON YIELD, ITS COMPONENTS AND GENOTYPIC STABILITY OF SOME NEW LINES OF GURMA WATERMELON (Citrullus colocynthoides) Ibrahim, E. A. \\ Veget. Res. Dept., Hort. Res. Inst., Agric. Res. Center, Giza, Egypt
}

\section{ABSTRACT}

Because saving irrigation water became a necessity recently, tolerant cultivars and different water management practices should be explored. Hence, two field experiments were carried out in a clay loam soil at Barramoon experimental farm, Hort. Res., Institute, Dakahlia Governorate, Egypt, during the two summer seasons of 2011 and 2012 to examine differences in yield and yield components among three new lines of gurma watermelon under three irrigation conditions (normal irrigation (4 irrigations), withholding last irrigation and withholding last irrigation with addition of humic acid), and to determine the lines stability for the different yield traits across irrigation conditions and identify the adapted lines. The results indicated that all studied traits were significantly decreased under water stress withholding last irrigation. But, adding humic acid in water deficit conditions increased significantly all studied characters more than under stress conditions in both seasons. Line s2 had significant more number of fruits per plant, seed yield per plant, 100-seed weight and seed yield per fedden than the other two lines in both seasons. The interaction between irrigation conditions and lines had significant effects on all studied traits in both seasons. On the other hand, the stability analysis showed that the mean sum of squares due to genotypes and genotypes $x$ environment (linear) indicated significant values for all studied traits. The variances due to environment + (varieties $\times$ environment) and environment (linear) were significant for all studied traits except number of fruits per plant. On the basis of stability parameters, $S_{2}$ was found to be most stable genotypes for yield attributing traits with high mean performance across different environments. Thus, this line can be used as new variety, also, it can be exploited in future breeding programs to develop high yielding and stable genotypes for water deficit conditions.

Keywords: Citrullus colocynthoides, gurma watermelon, water stress, humic acid and genotypic stability.

\section{INTRODUCTION}

Gurma watermelon (Citrullus colocynthoides) represents a significant amount of total Egyptian agricultural exports (Abo-Haded, 2003). The total area in Egypt was $174447 \mathrm{fed}$., with an average yield of $407 \mathrm{~kg} / \mathrm{fed}$. (EMALR, 2010). Moreover, its availability of plantation in different soils and environmental conditions makes it suitable for the new reclaimed lands. So, a great future is waiting its production in Egypt. However, its production has been confined to one variety. Thus, there is a need to increase the productivity of gurma watermelon with best quality through genetic improvement.

In Egypt, agriculture is expected to face less water availabilities in the near future (NWRP, 2001). The ability of plants to improve their resistance to 
Ibrahim, E. A.

drought plays an important role under adverse environmental conditions (Waseem et al., 2011).

Although the effects of water stress on growth and yield of watermelon plants have been studied during the last years, very little work has been done to study the effects of water stress on gurma watermelon in Egypt. For high yields, adequate water supplies are required during the total growing period (Erdem and Yuksel, 2003; Gonzalez et al., 2009). Fruit setting and filling stages are considered to be the most sensitive periods to water deficit stress (Erdem and Yuksel, 2003; Wakindiki and Kirambia, 2011). Gurma watermelon was more sensitive to drought than cultivated watermelon (Karipçin et al., 2008).

The application of organic products such as humic acid is one method that may reduce irrigation, improve the water use efficiency and decrease the effect of drought stress on differences between plant yield under stress and no stress (Haghighi et al., 2011). Humic acid is a suspension, based on potassium humates, which can be applied as a plant growth stimulant or soil conditioner. It improves soil physical property, ion exchange capacity and water holding capacity. Therefore, it improves plant growth and helps plants resist droughts (Hafez, 2004; Mikkelsen, 2005; Salman et al., 2005; El-Nemr et al, 2012)). Furthermore, the growth promoting activity of humic substances was found to be caused by plant hormone-like material contained in the humic substances (Zhang and Ervin, 2004).

The ability of specific cultivars or advanced breeding lines to produce high and satisfactory yield over a wide range of stress and non-stress environments is very important in plant breeding. By growing genotypes in different environments, the highest yielding and most stable genotypes would be more suitable as a cultivar and also as a donor parent for further breeding (Lu'quez et al., 2002). Therefore, it is important to understand the nature of genotype $x$ environment interaction to make testing and selection of genotypes more efficient.

Thus, this study was planned to evaluate three new lines of gurma watermelon grown under withholding last irrigation and using humic acid to raise the tolerant of this plant to stress conditions, as well as, their interaction on yield and yield components, and also to determine the stability of the gurma watermelon lines for the different traits across irrigation conditions and identify the adapted lines.

\section{MATERIALS AND METHODS}

Two field experiments were performed at Baramoon Experimental Farm, Dakahlia Governorate, Egypt, where the soil is Clay-loam, during the two summer seasons of 2011 and 2012. The genetic materials used in this investigation were three new lines $\left(S_{1}, S_{2}, S_{5}\right)$ in the $S_{6}$ generation, which were obtained from a previous research work conducted by Abd El-Rahman et al. (2005) and Ibrahim (2007) by using a pedigree selection program on the commercial cultivar of gurma watermelon.

Experimental design was split plot based on completely randomized blocks which replicated three times. The main plots were assigned to three 
irrigation conditions (normal irrigation (4 irrigations), withholding last irrigation and withholding last irrigation with addition of humic acid). Sub plots were devoted to three gurma watermelon new lines. Each experimental unit area was consisted of four ridges each of $5 \mathrm{~m}$ length and $1.5 \mathrm{~m}$ in width, and one plant per hill with $50 \mathrm{~cm}$ apart. Humic acid in a solid form as potassiumhumate ( $80 \%$ humic acid, $11-13 \%$ K2O) was used. Freshly prepared Humic acid suspension $(3 \mathrm{~g} / \mathrm{L})$ was applied as a soil drench twice before the first and second irrigation.

Seeds were sown on 28 and 26 March in both study seasons, respectively. Nitrogen in the form of ammonium sulfate $(20.6 \% \mathrm{~N})$ at a rate of $60 \mathrm{~kg} \mathrm{~N} / \mathrm{fed}$., phosphorus in the form of calcium superphosphate $(15.5 \%$ $\mathrm{P}_{2} \mathrm{O}_{5}$ ) at a rate of $30 \mathrm{P}_{2} \mathrm{O}_{5} / \mathrm{fed}$. and potassium in the form of potassium sulfate $\left(48 \% \mathrm{~K}_{2} \mathrm{O}\right)$ at a rate of $48 \mathrm{~kg} \mathrm{~K} \mathrm{~K}_{2} \mathrm{O} / \mathrm{fed}$. were applied at two equal doses, one was added after three weeks and the other after six weeks from planting. The culture practices were done according to the general program of gurma watermelon cultivation.

At harvest, a random sample of 8 plants was taken from each experimental unit to study the number of fruits per plant and seed yield per plant $(\mathrm{g})$. Moreover, fruit weight $(\mathrm{g})$, seeds weight per fruit $(\mathrm{g})$ and 100 -seed weight $(\mathrm{g})$ were recorded as the average data of 10 fruits per plot. Seeds were extracted, washed, dried and weighted. In addition, each plot was harvested and seed yield per fedden ( $g$ ) were determined.

Data obtained were statistically analyzed according to Snedecor and Cochran (1982). Differences among means were compared using the least significant difference value (L.S.D.). Moreover, data were analyzed to test the significance of genotype $x$ environmental interaction and stability parameters, $i$. e., regression coefficient (bi) and deviation from regression ( $\left.{ }^{2} \mathrm{di}\right)$ were computed by the method suggested by Eberhart and Russell (1966). For the regression analysis of variance, the residuals from the combined analysis of variance were used as a pooled error to test the $S^{2}$ di values. A significant $F$ value would indicate that the $S^{2}$ di was significantly different from zero. The hypothesis that each regression coefficient equaled unity was tested by t test using the standard error of the corresponding bi value.

\section{RESULTS AND DISCUSSION}

\section{Effect of irrigation conditions:}

Data listed in Table (1) show that the irrigation treatments had significant effects on fruit weight, seeds weight per fruit, number of fruits per plant, seed yield per plant, 100-seed weight and seed yield per fedden in the two summer seasons. Normal irrigation treatment was associated with the highest values of yield and yield components with significant differences as compared with withholding last irrigation in both seasons. But, adding humic acid in water deficit conditions increased significantly all studied characters more than under stress conditions in both seasons. Moreover, no differences were recorded in number of fruits per plant, seed yield per plant, 100-seed weight and seed yield per fedden between normal irrigation and the combination of water stress with humic acid in both seasons. 
Ibrahim, E. A.

1

2628 
The reduction in yield and yield components due to water stress during seeds filling might have been due to the inhibition in photosynthesis efficiency under insufficient water conditions (Huang et al., 2011; Waseem et al., 2011;). These results are in accordance with those reported by Erdem et al. (2001), Erdem and Yuksel (2003), Gonzalez et al. (2009) and Wakindiki and Kirambia (2011). Meanwhile, the increases may be ascribed to the role of humic acid on increasing the nutrients and water holding capacity of soil which helps plants resist drought (Mikkelsen, 2005). More recently, it was reported that humic acid contain cytokinins and their application resulted in increased endogenous cytokinin and auxin levels which possibly leading to improve plant growth under drought conditions (Zhang and Ervin, 2004).

\section{Lines differences:}

Data presented in Table (1) also show that lines were significantly differed in all studied characters in both seasons. Line $S_{5}$ significantly had better fruit weight and seeds weight per fruit than lines $S_{1}$ and $S_{2}$ in the two tested seasons. However, line $S_{2}$ had significant more number of fruits per plant, seed yield per plant, 100-seed weight and seed yield per fedden than the other two lines in both seasons. These results were in agreement with those found by Abd El-Rahman et al. (2005) who concluded that the genotypic variation between these lines might result in variation in yield and its components.

\section{Effect of Interaction between irrigation conditions and Lines:}

The interaction between irrigation conditions and lines had significant effects on all studied traits in both seasons (Table 1). The results clearly show that for all tested lines the water stress treatment had reductions in all studied traits, but reductions were lower with the application of humic acid when last irrigation was skipped. Among all lines, $\mathrm{S}_{2}$ had the highest yield and $S_{1}$ produced the lowest yield in optimal and stress conditions, respectively. These findings were similar in both experimental seasons. These results are aliened with those obtained by Erdem and Yuksel (2003) and Wakindiki and Kirambia (2011) who showed that the greatest variability among genotype in response to water availability at fruit filling stage. Moreover, the positive responses of all studied lines to the application of humic acid are supported by findings of Salman et al. (2005).

\section{Stability study:}

\subsection{Stability analysis:}

The analysis of variance for stability is presented in the Table (2). The results revealed that there were highly significant differences among the genotypes tested for all the characters studied except for number of fruits per plant, which was significant at 5 per cent level of significance. The significant differences in the genotypes under study may be used due to variation in their genetic make up.

The variance due to environment + (genotype $x$ environment) was found to be highly significant for all the characters whereas, number of fruits per plant was found to be insignificant. 
Ibrahim, E. A.

The effects due to environments (linear) were significant for all the characters except for number of fruits per plant. Significant mean square due to environments (linear) indicates the differences among environments and their considerable influence on these traits.

The mean sum of squares due to genotypes $\times$ environment (liner) interactions was tested against pooled deviation mean sum of square to find out significant effects due to genotype and environment separately. This demonstrated that genotypes respond differently to variation in environmental conditions and indicating existence of differences among the regression coefficients. This result is in accordance with Kumar et al. (2012) and Vasanthkumar et al. (2012). Hence, the partitioning was done as per Eberhart and Russell (1966) model in order to know the magnitude of linear and non linear components of variations which provide information on predictable and unpredictable sources of variations respectively, contributing to genotype $x$ environment interactions for all characters.

Table 2: Pooled analysis of variance for the studied yield components of gurma watermelon

\begin{tabular}{|c|c|c|c|c|c|c|c|}
\hline Source of variation & d.f & $\begin{array}{l}\text { Fruit } \\
\text { weight } \\
\text { (g) }\end{array}$ & $\begin{array}{c}\text { Seeds } \\
\text { weight } \\
\text { /fruit (g) }\end{array}$ & $\begin{array}{l}\text { No. } \\
\text { fruits/ } \\
\text { plant }\end{array}$ & $\begin{array}{l}\text { Seed } \\
\text { yield/ } \\
\text { plant } \\
\text { (g) }\end{array}$ & $\begin{array}{c}100- \\
\text { seed } \\
\text { weight } \\
\text { (g) }\end{array}$ & $\begin{array}{c}\text { Seed } \\
\text { yield/ } \\
\text { fed. (kg) }\end{array}$ \\
\hline $\bar{G}$ & 2 & 306 & $46.8^{* *}$ & $0.35^{*}$ & $325^{\star \star}$ & $9.6^{\star \star}$ & $5838^{* *}$ \\
\hline$E+(G \times E)$ & 15 & $82726^{\star *}$ & 20.5 & 0.05 & $321^{\text {** }}$ & $4.4^{* *}$ & $4203^{\text {** }}$ \\
\hline E (liner) & 1 & $81823^{\star *}$ & $19.1^{* *}$ & 0.04 & $304^{\star *}$ & $4.3^{*}$ & $4114^{* *}$ \\
\hline$G \times E$ (liner) & 2 & $733.2^{* *}$ & $0.9^{* *}$ & $0.69^{*}$ & $89^{*}$ & $4.0^{*}$ & $531^{*}$ \\
\hline Pooled deviati & 12 & 170.3 & 2.2 & 0.66 & 106 & 4.1 & 907 \\
\hline Pooled error & 36 & 6615 & 6.5 & 0.06 & 101 & 3.9 & 2421 \\
\hline
\end{tabular}

G: genotypes, E: environment

${ }^{*},{ }^{\star *}=$ Significant against pooled deviation M.S. at 5 and $1 \%$ levels, respectively.

\subsection{Stability parameters:}

The three stability parameters, viz., mean, regression coefficient (bi) and mean square deviation from regression line $\left(S^{2} \mathrm{di}\right)$ were estimated for the studied traits and presented in Table (3).

The stable genotypes are one which interact less with the environments giving a near consistent performance across different environments. According to Eberhart and Russell (1966), a variety is said to be stable when regression coefficient (bi) is close to unity and deviation from regression $\left(\mathrm{S}^{2} \mathrm{di}\right)$ is low and non-significant with high mean performance. Where, the regression coefficient measures the response of a genotype to a given environment and the deviation from regression measures the stability of performance. A genotype with (bi) value $<1.0$ has above average stability and is specially adapted to low-performing environments, a genotype with (bi) value $>1.0$ has below average stability and is specially adapted to high performing environments and a genotype with (bi) value equal to 1.0 has average stability and is well or poorly adapted to all environments depending on having a high or low mean performance but a genotype with $\mathrm{bi}=1.0$ and $\mathrm{S}^{2} \mathrm{di}=0.0$ may be defined as stable (Eberhart and Russell, 1966). 
Table 3: Estimation of stability parameters for yield traits in gurma watermelon

\begin{tabular}{|c|c|c|c|c|c|c|c|c|c|}
\hline \multirow{2}{*}{ Lines } & \multicolumn{3}{|c|}{ Fruit weight (g) } & \multicolumn{3}{|c|}{ Seeds weight/fruit (g) } & \multicolumn{3}{|c|}{ No. fruits/plant } \\
\hline & $\mathbf{X}$ & bi & $S^{2} \mathbf{d i}$ & $\mathbf{X}$ & bi & $S^{2} d i$ & $\mathbf{X}$ & bi & $S^{2} d i$ \\
\hline S1 & 547 & 0.98 & -176 & 29.7 & 1.07 & 0.34 & 2.68 & $4.27^{*}$ & -0.06 \\
\hline S2 & 506 & 0.91 & -156 & 31.2 & 0.60 & -0.04 & 2.88 & $4.08^{*}$ & -0.06 \\
\hline S5 & 607 & 1.11 & -177 & 33.7 & 1.17 & 0.03 & 2.54 & $3.91^{*}$ & -0.05 \\
\hline \multirow[t]{3}{*}{$\begin{array}{l}\text { Grand } \\
\text { mean }\end{array}$} & 553 & & & 31.5 & & & 2.70 & & \\
\hline & \multicolumn{3}{|c|}{ Seed yield/plant (g) } & \multicolumn{3}{|c|}{100 -seed weight $(\mathrm{g})$} & \multicolumn{3}{|c|}{ Seed yield/fed. (kg) } \\
\hline & $\mathbf{X}$ & bi & $S^{2} d i$ & $\mathbf{X}$ & bi & $\mathrm{S}^{2} \mathrm{di}$ & $\mathbf{X}$ & bi & $S^{2} \mathrm{di}$ \\
\hline S1 & 79.7 & 0.97 & $6.9^{\star \star}$ & 12.1 & -0.02 & 0.35 & 428 & 0.78 & 24.7 \\
\hline S2 & 90.1 & 0.50 & 3.3 & 13.2 & -0.43 & 0.08 & 472 & 1.03 & 38.0 \\
\hline S5 & 85.4 & 0.97 & $7.8^{* \star}$ & 11.5 & -0.05 & 0.28 & 452 & 0.98 & 36.7 \\
\hline $\begin{array}{l}\text { Grand } \\
\text { mean }\end{array}$ & 85.1 & & & 12.3 & & & 451 & & \\
\hline
\end{tabular}

$\mathrm{X}=$ Mean, bi=Regression coefficient, $\mathrm{S}^{2} \mathrm{di}=$ Deviation from regression

${ }^{*},{ }^{* *}=$ Significantly different from one for (bi) and from zero for $\left(\mathrm{S}^{2} \mathrm{di}\right)$ at $P=0.05$ and 0.01 , respectively.

Lines $S_{5}$ expressed maximum fruit weight with non-significant deviation from regression value and regression coefficient close to unity indicating stability for this trait.

Lines $S_{5}$ had above average seed weight per fruit, regression coefficient close to one (1.17) and with low deviation from regression (0.03) revealed wide adaptation and stability for seed weight per fruit across the tested environments.

Due to greater value of regression coefficient with high mean, line $S_{2}$ expressed below average stability and it is expected to give good number of fruits per plant under favorable environmental conditions. On the other hand, the significant estimated value of the parameter (bi) suggested that each of this line seemed to be more adapted, concerning the number of fruits per plant character, to the less favorable treatments (adding humic acid in water deficit conditions).

Line $\mathrm{S}_{2}$ has highest seed yield per plant $(90.1 \mathrm{~g})$ and its bi value is less than $1.0 \quad(b=0.50)$ with non significant deviation from regression, revealing its adaptability to unfavorable or poor environmental.

Line $S_{2}$ is specifically adapted to unfavorable environmental conditions having 100 -seed weight of $13.2 \mathrm{~g}$ and a regression value less than one $(-0.43)$ with non-significant standard deviation.

Lines $S_{2}$ and $S_{5}$ recorded the higher mean values of seed yield per fedden compared with population mean and their regression coefficient were near to unity with non significant deviation from regression, hence genotypes are stable for seed yield per fedden across the tested environments. Such varied responsiveness of genotypes to changing environments was also reported by Narayan et al. (2006) in bitter gourd and Kumar et al. (2012) and Vasanthkumar et al. (2012) in watermelon. 
Ibrahim, E. A.

\section{Conclusion}

Because saving irrigation water became a necessity recently, tolerant lines and different water management practices should be explored. It is concluded from the results of this study that expose the gurma watermelon lines to withholding last irrigation leads to significant decreases in yield and its components but the reductions can be minimize by adding humic acid ( 3 $\mathrm{g} / \mathrm{L}$ ). The response to the water stress conditions depends on the line used. Line $S_{2}$ that had the higher mean seed weight per fruit, seed yield per plant, 100 -seed weight and seed yield per fedden across the tested irrigation environments can be suitable for cultivation under unfavorable irrigation conditions and water deficit conditions with the application of organic products such as humic acid. This line also can be exploited in future breeding programs to develop high yielding, stable genotypes for water deficit conditions.

\section{REFERENCES}

Abd El-Rahman, M.M.; M.E. Abo El-Nasr and E.A. Ibrahim (2005). Improving the productivity of gurma melon (Citrullus colocynthoides) through inbreeding and selection. J. Agric. Sci. Mansoura Univ., 30 (11): 66356641.

Abo-Haded, A. (2003). "The Egyptian agricultural exports" Annual Foreign Trade Bulletin (CAMPAS) Bulletin of Commodity Consumption in Egypt-separate issues-Cairo.

Eberhart, S.A. and W.L. Russell (1966). Stability parameters for comparing varieties. Crop Sci., 6: 36-40.

El-Nemr, M.A.; M. El-Desuki; A.M. El-Bassiony and Z.F. Fawzy (2012). Response of growth and yield of cucumber plants (Cucumis sativus L.) to different foliar applications of humic acid and bio-stimulators. Australian Journal of Basic and Applied Sciences, 6 (3): 630-637.

EMALR (Egyptian Ministry of Agriculture and Land Reclamation), 2010, Agricultural Statistics, Economic Affairs Sector, Giza, ARE.

Erdem, Y. and A.N. Yuksel (2003). Yield response of watermelon to irrigation shortage. Scientia Horticulturae, 98: 365-383.

Erdem, Y.; A.N. Yuksel and A.H. Orta (2001). The effects of deficit irrigation on watermelon yield, water use and quality characteristics. Pakistan J. Biol. Sci., 4 (7): 785-789.

Gonzalez, A.M.; S. Bonachela and M. D. Fernandez (2009). Regulated deficit irrigation in green bean and watermelon greenhouse crops. Sci. Hort., 122: $527-531$.

Hafez, M.M. (2004). Effect of some sources of nitrogen fertilizer and concentration of humic acid on the productivity of squash plant. Egypt. J. Appli. Sci., 19: 293-309.

Haghighi, S.; T. Saki Nejad and S. Lack (2011). Effect of biological fertilizer of humic acid on metabolic process of biological nitrogen fixation. Life Science Journal, 8 (3): 43-48. 
Huang, Z.; Z. Zhirong; H. Chaoxing; H. Zhongqun; Z. Zhibin and L. Jianming (2011). Physiological and photosynthetic responses of melon (Cucumis melo L.) seedlings to three Glomus species under water deficit. Plant and Soil, 339 (1-2): 391-399.

Ibrahim, E.A. (2007). Heritability, heterosis and correlation coefficient for yield and yield components of $F_{1}$ 's hybrids among new selected inbred lines of gurma watermelon (Citrullus colocynthoides). J. Agric. Sci. Mansoura Univ., 32 (7): 5601-5608.

Karipçin Z.; N. Sari and H. Kirnak (2008). Preliminary research on drought resistance of wild and domestic Turkish watermelon accessions. Pitrat M. (ed): Cucurbitaceae, Proceedings of the IXth EUCARPIA meeting on genetics and breeding of Cucurbitaceae, Avignon (France), May 21 24th, pp. 493-499.

Kumar, V.; A.M. Shirol; R. Mulge; N. Thammaih and P. Kumar (2012). Genotype $\mathrm{x}$ environmental interaction in watermelon (Citrullus lanatus Thunb.) genotypes for yield and quality traits. Karnataka Journal of Agricultural Sciences, 25 (2): 248-252.

Lu'quez, J.E.; L.A.N. Aguirreza'bal; M.E. Aguero and V.R. Pereyra (2002). Stability and adaptability of cultivars in non-balanced yield trials: Comparison of methods for selecting 'high oleic' sunflower hybrids for grain yield and quality. Crop Sci.,188 (4):225-234.

Mikkelsen, R.L. (2005). Humic materials for agriculture. Better Crops, 89 (3): 6-10.

Narayan, R.; N. Ahmed and S. Mufti (2006). Evaluation of some bitter gourd genotypes for yield traits and genetic parameters under Kashmir conditions. Ecol. Environ.,24S(Special 3A): 750-752.

NWRP (2001). National water resource plan for Egypt. Interim report no. 1. Ministry of Water Resources and Irrigation-Planning Sector, Cairo- May 2001, 205pp.

Salman, S.R. ; S.D. Abou-hussein, A.M.R. Abdel-Mawgoud and M.A. ElNemr. (2005). Fruit yield and quality of watermelon as affected by hybrids and humic acid application. Journal of Applied Sciences Research, 1(1): 51-58.

Snedecor, G.W. and W.G. Cochran (1982). Statistical Methods. $7^{\text {th }}$ Ed., $2^{\text {nd }}$ Printing, lowa State Univ. Press, Ame., USA, 507 PP.

Vasanthkumar; A. M. Shirol; R. Mulge; N. Thammaih and Prasadkumar (2012). Genotype x environmental interaction in watermelon (Citrullus lanatus Thunb.) genotypes for yield and quality traits. Karnataka J. Agric. Sci., 25 (2): 248-252.

Wakindiki, I. I. C. and R. K. Kirambia (2011). Supplemental irrigation effects on yield of two watermelon (Citrulus lanatus) cultivars under semi-arid climate in Kenya. African Journal of Agricultural Research, 6 (21): 4862-4870.

Waseem, M.; A. Ali; M.Tahir; M. A. Nadeem; M. Ayub; A. Tanveer; R. Ahmad and M. Hussain. (2011). Mechanism of drought tolerance in plant and its management through different methods. Continental J. Agricultural Science, 5 (1): 10 - 25. 


\section{Ibrahim, E. A.}

Zhang, X. and E. H. Ervin (2004). Cytokinin-containing seaweed and humic acid extracts associated with creeping bent grass leaf cytokinins and drought resistance. Crop Sci., 44: 1737-1745.

\section{تأثير مستويات مختلفة من الاجهاد المائي وإضافة حمض الهيوميك على المحصول} ومكوناته والثبات الوراثي لبعض الأبرات السلالات الجديدة من بطيخ اللب (الجورمة) إيهاب عوض الله إبرات الهرايم قسم بحوث الخضر - معهل بحوث البساتين- مركز البحوث الززراعية. الجيزة- مصر

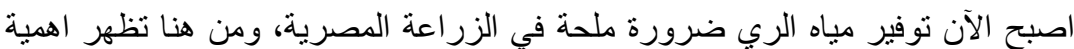

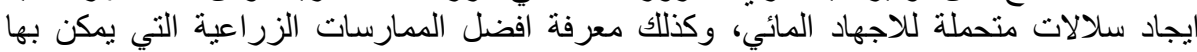

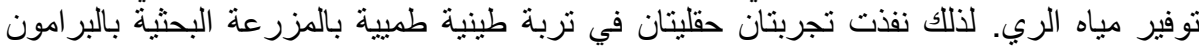

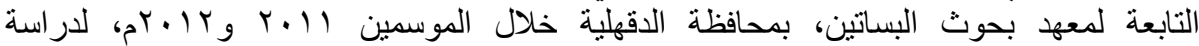

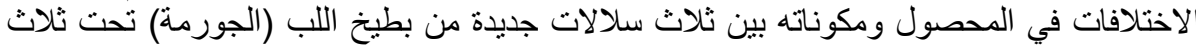

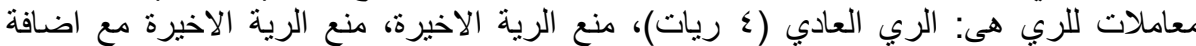

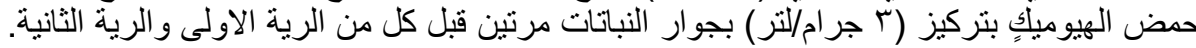

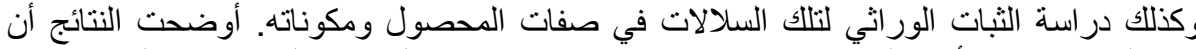

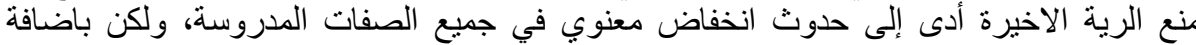

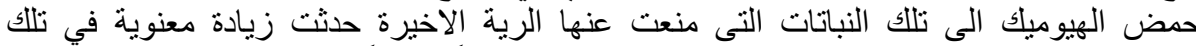

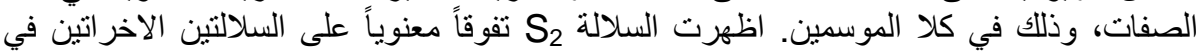

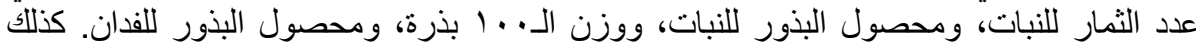

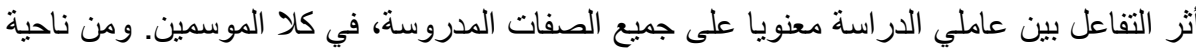

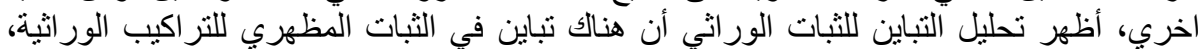

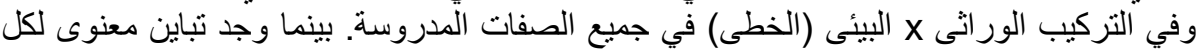

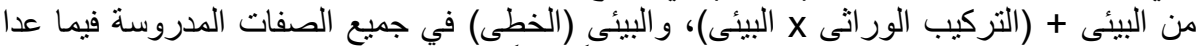

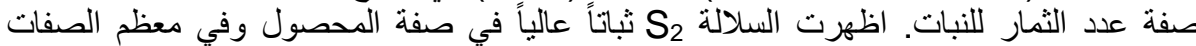

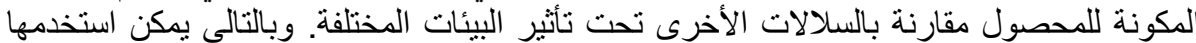

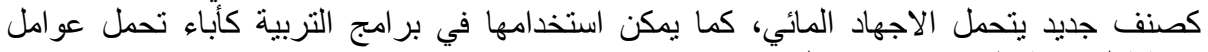
ور اثية لدقاومة ظروف الاجهاد المائي.

كلية الزراعة - جامعة المنصورة

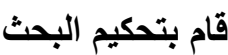

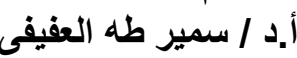
أ.د / حمدى حسن الضوينى طنى الفنى 
J. Plant Production, Mansoura Univ., Vol. 3 (10), October, 2012 
Ibrahim, E. A.

2636 
Table 1: Effect of irrigation conditions, gurma watermelon Lines and their interactions on all studied yield traits during 2011 and 2012 seasons

\begin{tabular}{|c|c|c|c|c|c|c|c|c|c|c|c|c|c|}
\hline \multicolumn{2}{|c|}{\begin{tabular}{|c|} 
Treatments \\
\end{tabular}} & \multirow{2}{*}{\multicolumn{2}{|c|}{$\begin{array}{l}\text { Fruit weight } \\
\text { (g) }\end{array}$}} & \multirow{2}{*}{\multicolumn{2}{|c|}{$\begin{array}{l}\text { Seeds weight / } \\
\text { fruit }(\mathrm{g})\end{array}$}} & \multirow{2}{*}{\multicolumn{2}{|c|}{$\begin{array}{l}\text { No. fruits/ } \\
\text { plant }\end{array}$}} & \multirow{2}{*}{\multicolumn{2}{|c|}{$\begin{array}{l}\text { Seed yield } / \\
\text { plant }(\mathbf{g})\end{array}$}} & \multirow{2}{*}{\multicolumn{2}{|c|}{$\begin{array}{c}\text { 100-seed weight } \\
\text { (g) }\end{array}$}} & \multirow{2}{*}{\multicolumn{2}{|c|}{$\begin{array}{l}\text { Seed yield/ } \\
\text { fed. }(\mathbf{k g})\end{array}$}} \\
\hline \multirow{2}{*}{$\begin{array}{l}\text { Irrigation } \\
\text { conditions }\end{array}$} & \multirow{2}{*}{ Lines } & & & & & & & & & & & & \\
\hline & & 2011 & 2012 & 2011 & 2012 & 2011 & 2012 & 2011 & 2012 & 2011 & 2012 & 2011 & 2012 \\
\hline \multirow{3}{*}{\multicolumn{2}{|c|}{\begin{tabular}{|l} 
Normal irrigation \\
Stress \\
Stress $+\mathrm{HA}^{*}$
\end{tabular}}} & 611 & 618 & 32.51 & 32.68 & 2.74 & 2.72 & 88.81 & 88.84 & 12.71 & 12.75 & 465 & 472 \\
\hline & & 458 & 461 & 30.13 & 30.12 & 2.66 & 2.61 & 80.10 & 78.67 & 11.63 & 11.58 & 429 & 435 \\
\hline & & 588 & 585 & 31.78 & 31.76 & 2.74 & 2.75 & 86.77 & 87.19 & 12.49 & 12.51 & 451 & 453 \\
\hline \multicolumn{2}{|l|}{ LSD (5\%) } & 18 & 21 & 0.62 & 0.53 & 0.05 & 0.06 & 2.99 & 3.10 & 0.60 & 0.59 & 15 & 20 \\
\hline & $\mathrm{S} 1$ & 548 & 547 & 29.63 & 29.69 & 2.69 & 2.68 & 79.83 & 79.53 & 12.12 & 12.14 & 426 & 431 \\
\hline & S2 & 503 & 509 & 31.17 & 31.33 & 2.90 & 2.87 & 90.36 & 89.78 & 13.25 & 13.22 & 470 & 474 \\
\hline & S5 & 606 & 607 & 33.64 & 33.53 & 2.54 & 2.54 & 85.49 & 85.39 & 11.46 & 11.48 & 450 & 455 \\
\hline \multicolumn{2}{|l|}{ LSD (5\%) } & 21 & 27 & 0.83 & 0.73 & 0.07 & 0.08 & 2.77 & 2.03 & 0.60 & 0.60 & 11 & 15 \\
\hline \multirow{3}{*}{$\begin{array}{l}\text { Normal } \\
\text { irrigation }\end{array}$} & S1 & 601 & 614 & 30.76 & 30.95 & 2.73 & 2.71 & 83.88 & 83.84 & 12.61 & 12.65 & 439 & 445 \\
\hline & S2 & 555 & 560 & 31.98 & 32.04 & 2.91 & 2.88 & 93.08 & 92.24 & 13.65 & 13.69 & 489 & 495 \\
\hline & S5 & 676 & 680 & 34.80 & 35.05 & 2.57 & 2.58 & 89.46 & 90.45 & 11.87 & 11.91 & 468 & 476 \\
\hline \multirow{3}{*}{ Stress } & S1 & 459 & 451 & 28.09 & 28.12 & 2.61 & 2.59 & 73.35 & 72.85 & 11.38 & 11.35 & 409 & 414 \\
\hline & S2 & 415 & 425 & 30.20 & 30.55 & 2.87 & 2.80 & 86.69 & 85.55 & 12.77 & 12.62 & 449 & 454 \\
\hline & S5 & 501 & 505 & 32.11 & 31.67 & 2.50 & 2.45 & 80.26 & 77.60 & 10.75 & 10.76 & 430 & 437 \\
\hline \multirow{3}{*}{ Stress + HA } & $\mathrm{S} 1$ & 583 & 575 & 30.03 & 30.01 & 2.74 & 2.73 & 82.27 & 81.90 & 12.38 & 12.40 & 430 & 433 \\
\hline & S2 & 540 & 543 & 31.32 & 31.40 & 2.92 & 2.92 & 91.32 & 91.56 & 13.34 & 13.35 & 473 & 474 \\
\hline & S5 & 642 & 636 & 34.00 & 33.88 & 2.55 & 2.60 & 86.74 & 88.10 & 11.75 & 11.78 & 450 & 452 \\
\hline \multicolumn{2}{|l|}{ LSD (5\%) } & 37 & 47 & 1.43 & 1.27 & 0.11 & 0.13 & 4.79 & 3.51 & 1.03 & 0.99 & 22 & 27 \\
\hline
\end{tabular}

${ }^{*}=$ Humic acid 